\title{
Early 20th Century Examples of Stakeholder Reporting from U.S. Corporate Annual Reports
}

\author{
Kevin Feeney \\ Solbridge International School of Business Dae Jeon Korea \\ kfeeney@solbridge.ac.kr
}

\begin{abstract}
The content of traditional annual reports for publicly owned corporations is undergoing significant change. Whether in the traditional printed form, or increasingly, via web-based formats, annual reports are moving beyond the mere reporting of the fiscal year's financial results. Corporate annual reports are beginning to include supplemental disclosures on the corporation's labor and supplier activities environmental activities, governance, social responsibility and, most recently, sustainability. This trend has been observed more frequently for corporations based outside of the United States, though a small number of U.S corporations have embraced these concepts as well. Such supplemental disclosures are made not only to its shareholders, but also to individuals, groups and other entities that have a direct stake (i.e. stakeholders) in the corporation's activities, successes and/or other matters at hand. This paper looks at the development of the stakeholder model and some of groups involved in the expansion of annual reports to include their concerns. Looking back historically, the paper examines early examples of stakeholder reporting from 20th Century annual reports of Ford Motor Company and by certain publicly owned U.S. railroads. Lastly, the paper provides evidence of an earlier example of stakeholder reporting then that previously identified in the literature.
\end{abstract}

Key words: Annual reports, accounting history, voluntary reporting, stakeholders, supplemental reporting

\section{Stakeholders}

Corporations were created to benefit their shareholders and their early annual reports were directed solely to them. As funding and capital needs increased, corporations began to borrow money both on an informal (such as account payable) and a formal (such as bonds) basis and their annual reports evolved to include information on debt levels, liquidity and covenant compliance that was of interest to creditors. However, corporations have long had extensive business relationships with many other parties including individuals, other businesses, governments, etc. While these other parties were not entitled to a share of profits nor did they have claims against corporate assets, nevertheless, these parties were often greatly affected or impacted by various corporate actions. By the later part of the $20^{\text {th }}$ century, a notion began to develop that corporations were (and should be) responsible to more than just their shareholders and creditors. Collectively, these other parties have come to be called stakeholders because they have a stake in the continuation of the firm and/or its business activities. It is believed the term stakeholder was first used in 1963 and that its widespread usage in the literature begin only after publication of R. Edward Freeman's seminal paper, "Strategic Management: A Stakeholder Approach," in 1984 (Lawrence and Weber, 2011).

\section{Corporate stakeholders can include all or some of the following groups/entities:}

\begin{tabular}{ll}
\hline stockholders, & suppliers, \\
service providers, & creditors, \\
employees, & labor unions, \\
customers, & communities, \\
local \& state governments, & federal government, \\
regulators, & non-governmental organizations, \\
public-at-large, & business and trade associations, \\
media, & investment fund managers,
\end{tabular}

$>$ and certain other businesses. 
The needs of the various stakeholders are not all the same. While some needs, may overlap or be complementary, more often the needs are competing. This situation complicates the annual reporting because clearly one message will not fit all. In an attempt to address this reporting dilemma, various organizations have become involved. One of these is the Center for Advancement of Public Policy (CAPP) that was founded in 1991. This organization has certain social objectives such as the elimination of prejudice, sexism and discrimination in both the workplace and society in general. It also pushes for "more responsible capitalism" by having corporations become fully accountable to all of their stakeholders including the greater society. The later concept includes not only the "the earth and it environments, but also future generations" (capponline.org).Together with other like-minded organizations and individuals, the CAPP formed The Stakeholder Alliance, which seeks to hold corporations fully accountable to all stakeholders for their actions. Its primary means to accomplish this result are The Sunshine Standards, which provide four disclosure standards intended to extend, and also compliment, the financial reporting and disclosures promulgated by the Financial Accounting Standards Board (FASB) in the U.S.A. The Alliance believes that while the Securities and Exchange Commission mandates reporting to stockholder and bondholders, other stakeholders should also be entitled to no less than full and fair disclosures of all corporate actions affecting them (capponline.org).Not wanting to be left out of the development of this new reporting paradigm, the accounting profession in U.S. and Canada has recently become involved. In November of 2009, the Chairman of the American Institute of CPAs (AICPA) discussed the new paradigm in a new video (Corporate Reporting to Stakeholders. Blog) and the AICPA later issued an extensive set of frequently asked questions (FAQ) on accounting for sustainability and other stakeholder reporting issues. The Charted Accountants in Canada (CICA) issued a major research study, Corporate Reporting to Stakeholders, in June 2008. This study provided helpful guidance on "comprehensive and integrated corporate reporting." Interestingly, the CICA study said the corporate reporting is the process of communicating with stakeholders, regardless of the media or vehicle actually used for the communication (CICA.ca).

\section{Stakeholder Reporting Internationally}

Any web search on corporate stakeholder reporting outside of the U.S. will generate scores of results. Several of the more salient ones are included in this section of the paper. Toyota (Japan) has held an annual "Stakeholder Dialogue" since 2001(toyota.com). At each dialogue, Toyota meets with representatives of its worldwide stakeholders to both receive their expectations/opinions and to report on various Toyota activities. Several producers of electricity have embraced stakeholder reporting, possibly as a way to address public concerns of their environmental impacts. This would include companies such as National Grid (UK) and Eskom (ZA) (2011). Among the more expansive stakeholder reports seen on various websites were those of Unilever (UK-Dutch), Johnson Mattley (UK) and Imperial Tobacco Group (UK). While these companies are have made stakeholder reporting an integral part of their corporate philosophy with clear and concise reporting, this not the case with all international companies. For example, DeBeers Group ${ }^{1}$ (Luxembourg) produced its first report to stakeholders for 2005/2006 (issued in February 2007) which was variously described as "lacking real sparkle." Critics cited the length of the report and the lack of any prioritization of the issues mentioned. In addition, while substantial quantitative data was disclosed, the most important information was seemingly buried in a lengthy narrative (Ethical Corp.com).Its latest report, Report to Society 2010, was issued in June 2011 (debeersgroup.com) and seems to have addressed the prior criticisms.

Stakeholder Reporting in the U.S.A.: Similar web searches generated substantial mentions of recent stakeholder reports for various U.S. organizations and at least one source, the Corporate Social Responsibility Newswire (www.csrwire.com) seemingly devoted to this type of supplemental reporting. However, only a handful of the search results were actually for publicly owned, corporations. The vast majority of the hits were from various not-for-profits, non-governmental organizations, governments and their political subdivisions, churches, as well as educational institutions at all levels. The earliest formal stakeholder report observed was Harley Davidson's 1999 annual report, which includes a message to its employee and its desire

\footnotetext{
${ }^{1}$ This company is the world's largest producer of diamonds.
} 
to "develop a mutually beneficial relationship with all of (its) stakeholders". One company with an extensive history in this regard is Whole Foods whose annual report has actually been called the "Annual Stakeholders' Report" at least since 2003. Starbucks' first demonstrated its commitment to stakeholder engagement in its 2004 annual report that also included information about the company's corporate social responsibilities (CRSwire.com). In its 2006 annual report, Timberland reaffirmed its commitment to objective and transparent reporting by including a team of external stakeholders to formally review its annual report and, by two years, later made several leading-edge changes to its annual report format and had its entire reporting process reviewed by a Coalition Environmentally Responsible Economies (Ceres) convened stakeholder group(CRSwire.com).The few U.S. corporations that have implemented supplemental stakeholder reporting are generally socially conscious firms that also make sales directly to the consuming public.

\section{Historical Stakeholder reporting in the U.S.}

Hudack and Orsini (1998) said that Ford Motors Company had "a relatively impressive track record that demonstrated a receptive attitude about financial reporting to (its) stakeholders."Their literature review included Niemark (1992) who said the annual reports are useful for companies "to construct themselves and their relationships with others," and they saw their paper as an extension of Niemark's work that claimed the General Motors' annual reports from the 1960s included some of the best example of the stakeholder model, albeit years before that term was in common usage. Hudack and Orsini (1998) reviewed Ford's annual reports for 42 years $(1955$ - 1997) and found that its reports from the 1955 to 1979 period did a "superior job" in financial disclosure as compared to most publicly held, U.S. corporations. The basis for their conclusion was that Ford provided a supplemental allocation of revenue to its stakeholders: suppliers, employees, government, investors and the company itself. As to the motivation for this seemingly voluntary disclosure, Hudack and Orsini (1998) suggested it came from Ford's well-documented teamwork concept that included both its employees and suppliers as integral constituents. However, Hudack and Orsini (1998) did not consider certain 1955 events that may have in fact provided Ford's motivation for supplemental disclosure in the first place. The format of Ford's supplemental allocation of revenue disclosure was relatively consistent during the 1955 to 1979 period and included the following five categories:

- Suppliers: materials, supplies, services, etc.

- Employees: wages, salaries and benefits

- Depreciation, depletion and amortization

- Taxes (exclusive of exercise taxes)

- Net income- both in total and further broken down into dividends and that retained in the business.

However, the graphic device that Ford used to present the supplemental information changed in 1962 to pie charts and other proportional formats. ${ }^{2} \mathrm{~A}$ pie chart format is arguably more useful as it readily allows the reader to easily gauge the relative amounts of the various categories being disclosed. Indeed, when Hudack and Orsini (1998) presented summary information about Ford's average allocation by stakeholders during two periods, they used the pie chart format (Exhibit I on page 11). From 1972 through 1979, Ford presented the supplemental disclosure in a monetary format as either percentage of a dollar, or in cents. The monetary formats included pictures of: dollar bills, the obverse of a silver dollar coin, and the reverse of an Eisenhower dollar coin and, in just the 1974 report, stacks of U.S. coins. Hudack and Orsini (1998) also found that the supplemental disclosures appeared to increase in importance in the 1955 to 1979 period as evidenced by its actual location in the annual report, which changed over time. Beginning in 1972, and continuing through 1979, the supplemental disclosures appeared on the front inside either cover or page 1 of the annual report. However, in Ford's 1980 annual report the supplemental disclosure disappeared without any explanation and did not reappear in subsequent reports. Hudack and Orsini (1998) contributed this action to a number of social, political and economic factors, notably Ford's record losses that resulted from the serious recession in the late 1970sand caused a significant reduction in its dividends. In looking at the annual reports for Ford's first twenty-five years as a publicly-owned company, Hudack and Orsini (1998) made no mention of two

${ }^{2}$ Relevant examples of the Ford disclosures from Hudick et al. paper are included in the Appendix of this paper. 
significant events that took place in 1955 that may have provided the initial motivation for the supplemental disclosure. Even in 1955, Ford Motor Company was well established, having been founded by Henry Ford back in 1903. However, unlike the other two members of the Big Three automakers - GM and Chrysler, Ford was privately owned by the Ford Foundation ${ }^{3}$ and members of the extended Ford family. At that time, the Ford Foundation was the largest philanthropy in the world and had undertaken studies on diversifying its investment in Ford Motors. The result of these studies was the decision for the Foundation to sell some of its Ford shares in an initial public offer (IPO). This offering was publically announced just after 10 a.m. on December 211955 when Ford's registration statement was filed with the Securities and Exchange Commission. In its headline the next day, The Baltimore Sun said "Ford Company Reveals Its Financial Secrets" in the filing. The Pittsburgh Press described the offering, 10.2 million shares at \$75, as the largest corporate offering in (then) U.S. history.

From the history section of the Ford Foundation website, it can be learned that among its stated purposes (as adopted in 1950) were: the advancing the economic well-being of people everywhere and improving economic institutions for the better realization of democratic goals. Given that the leadership of the Ford Motor Company and the Ford Foundation at that time were the same (Henry Ford II), it is not inconceivable that message in the Ford's first annual report to the public would be reflective of the Foundation's stated objectives. Accordingly, inclusion of the supplemental disclosure showing the annual allocation of Ford Motor's revenue (including that to its employees) would seemingly meet the Foundation's stated objectives. Also, technically, at the end of 1955Ford was still privately-held since the actual IPO did not take place until early in 1956.Perhaps, it is just a coincidence that the supplement stakeholder disclosures stopped a few years after the Foundation had sold off the majority of its Ford stock in the mid-1970s. The other significant event in 1955 that may have influenced the supplemental disclosure was the agreement that Ford signed with its union, the United Auto Workers(UAW), on June $6^{\text {th }}$ of that year.

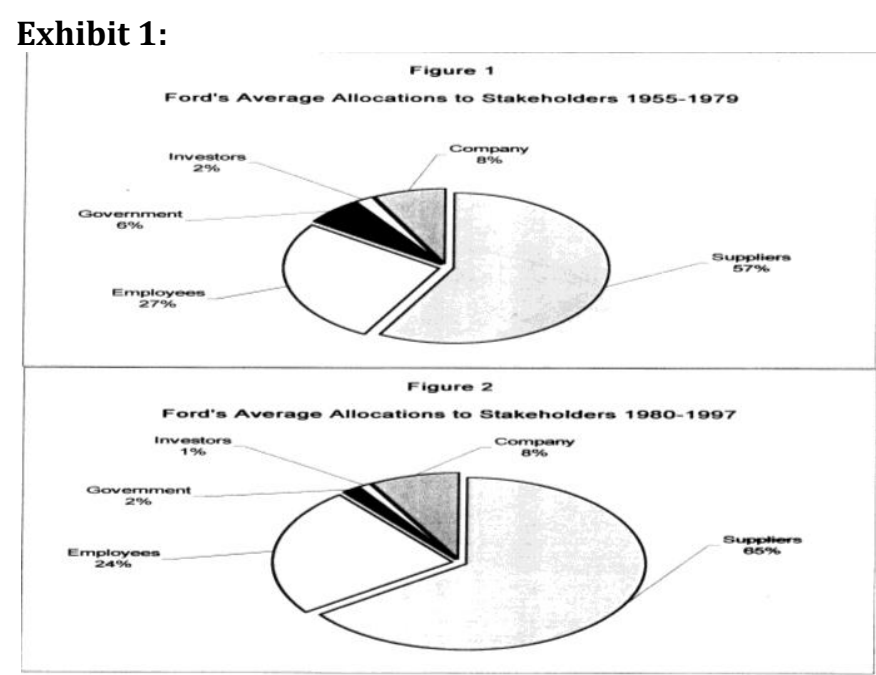

Source: These two figures were not actually part of the Hudack and Orsini (1998) paper, but rather were distributed during its presentation at which this writer was in attendance.*

A June 16, 2003 article in Automotive News called that agreement "revolutionary" in that, for the first time, Ford agreed to guarantee an annual wage to any laid-off hourly workers. This supplemental unemployment benefit (commonly known as SUB pay) together with state unemployment benefits could total up to 65\% of the normal take-home pay for Ford's 140,000 unionized employees. Agreeing to provide the SUB pay averted a UAW threatened strike at Ford in 1955 and subsequently both GM and Chrysler adopted similar programs

\footnotetext{
${ }^{3}$ As the result of deaths of Edsel Ford in 1943 and Henry Ford in 1947, the Ford Foundation website says it held a significant interest in non-voting stock in Ford Motors. One source (Funding Universe) said that this amounted to a $90 \%$ interest.
} 
for their unionized employees. Interestingly, as part of the negotiations, Ford had offered its UAW employees the opportunity to buy stock (pre IPO) in the company at half price, but the union rejected that proposal. Ford had a long history of a progressive labor policy dating back to Henry Ford's decision to pay better-thanaverage wages when building the Model T, as well as hiring blacks and disabled workers before other companies generally would do so. Even the creation of the Ford Foundation in 1936 was consistent with Henry Ford's belief in helping people to help themselves (Funding Universe). Given that Ford's labor costs were significant ${ }^{4}$, it is reasonable to assume that it would want to disclose them in its annual report in some fashion. The supplemental allocation of revenue charts were a convenient and effective way to do so.

\section{U.S. Railroads}

As it turns out, Ford Motor was not the first U.S. publicly owned corporation whose annual report included supplemental allocation of revenue disclosures. Feeney (2004) performed content analysis on the public annual reports for a judgmental sample of 20 Class 1 railroads ${ }^{5}$ from 1946 through 1975 . He found that the format, accounting and disclosure practices in the selected annual reports changed as the sampled railroads voluntarily moved from an Interstate Commerce Commission (ICC) based reporting model to a (U.S.) GAAP based accounting and reporting. Among his specific findings was that while the average size of the annual report decreased during the study period, the sampled railroads made increased use of graphic elements. Among the graphic elements presented, one, the so-called railroad dollar6, was widely used. However, while the railroad dollar graphic was similar to the format of Ford's supplemental allocation of revenue disclosure from the late 1960s through 1979, the railroad one was more detailed in that it also usually also included the allocation of the incoming revenue dollar among various types of customers (who were also stakeholders)? Furthermore, the railroads' usage of this graphic device predates Ford's usage by a decade! Beyond individual railroad annual reports, Feeney found that a composite distribution of the revenue dollar for all Class I railroads was regularly included in various annual publications issued by the Association of American Railroads from the 1950s through the mid-1970s. Feeney found $25 \%$ of the sampled railroads $(\mathrm{n}=20)$ presented the railroad dollar in 1946 and that usage of this graphic element increased over time such that, by $1959,60 \%$ of the sample included it in their annual reports. Even though railroad employees (a major stakeholder) were not likely ${ }^{7}$ to own stock in their employer, many railroads, nevertheless, distributed annual reports to their workers through actual copies of the reports, special employee editions or inclusion of annual report highlights into monthly employee magazines, He concluded that the railroad dollar was a very effective way to convey the fact that railroads earned only a small profit from each revenue dollar and this seems to be the primary motivation for using it. After the end of World War II, the railroad industry was in protracted battles with their largely unionized workforce over rates of pay, hours of service and work rules. Yet, this was a time when railroad labor costs were often more than half of each revenue dollar, far more than at other industries. Indeed, a railroad industry text of that era (Bunnel, 1955) recommended the use of graphic presentations in annual reports to overcome the railroad workers' limited education and their widely held belief of high industry profitability.

Looking to expand on Feeney's study, this writer flew to the Mercantile Library in November 2010. The Mercantile Library is located on the campus of the University of Missouri-St. Louis (UMSL) and among its specialized collections is the Barriger Collection. John Barriger was an executive with several railroads and one of the industries is leading strategists through his death in 1976. The Barriger Collection includes virtually every annual report issued by U.S. publicly owned railroads in the $20^{\text {th }}$ century. Through a personal review of hundreds of annual reports, this writer found that railroad dollar graphic appeared in more annual

\footnotetext{
${ }^{4}$ Labor costs averaged $27 \%$ of each revenue dollar for $1955-1979$.

5 U.S. Railroads have long been classified into different groups by the ICC (based on revenue) for statistical purposes. Class 1 railroads are those with the largest revenue. The minimum threshold for this classification has changed over time; it was \$1 million in 1946 and \$10 million in 1975.

${ }^{6}$ Five examples of the railroad dollar graphic are included in the Appendix section of this paper.

${ }^{7}$ This was an era well before employee stock purchase plans and broad-based stock options plans were made available to rank and file employees.
} 
reports than the 20 railroads $^{8}$ in Feeney's study. Furthermore, this writer observed that the very first appearance of the railroad dollar graphic was in the 1942 annual report of the Erie Railroad (Exhibit 2 on page 16). The 1942 report was issued in early 1943. Also found in the Barriger Collection was a 1946 book by Joseph White, (1946) entitled Analysis of Railroad Operations. Its title is misleading as was aptly pointed out by Leonard in a book review published in 1948. The book is actually a guide to railroad accounting practices presented through a comprehensive analysis of the financial statements of two unnamed Class 1 railroads. However, to students of railroad history, it is obvious that one of two is clearly the Erie Railroad. Interestingly, White presented a pie chart (Exhibit 3 on page17) showing the average distribution of the revenue dollar for all Class 1 railroads that is virtually identical to the Erie's 1942 presentation noted above. Still, the publication of White's book in 1946 predates the various 1946 annual reports that the railroads issued in early 1947 with the railroad dollar graphic, such that White's book may have been the actual catalyst for its observed early use. It is not surprising that railroad may have been the first public corporations to have had this early form of stakeholder reporting. Railroads were among the first publicly owned companies in the U.S. While a predecessor company to Baltimore Gas \&Electric is generally acknowledged as issuing the first annual report in the U.S. to its shareholders in 1825 (Investors Relations Magazine, 2000), the Baltimore \& Ohio (B\&O) Railroad was chartered in 1827 as the first publicly-owned railroad in the U.S. and it issued an annual report for its first year of operations (Previts and Samson, 2000). Vangermeersch (1979) described the B\&O as the first major railroad in the country and quoted the author of its hundred-year history as saying it was a "railroad university." Vangermeersh also said that the B\&O's disclosures influenced not only other railroads, but also set the stage for what would be disclosed in the annual reports of large-scale industrial corporations much later in the $19^{\text {th }}$ century. Indeed, Privets \& Samson, (2000) found that the style and content of the B\&O annual reports from 1827 to1856 influenced the annual reports of other railroads, notably the Louisville\& Nashville and the Illinois Central. They also said (p.36) that a picture that appeared in the B\&O's 1830 annual report was the first known use of a technical illustration in U.S. corporate annual reporting. Feeney observed that in the mid part of the $20^{\text {th }}$ century, railroad annual reports were widely distributed to officials at other railroads, industrial customers, suppliers and various other (stakeholder) groups besides the stockholders. It is quite conceivable that Ford, a major freight customer, received an annual report from one of the railroads that served the Detroit, Michigan area in the early 1950s and that included the railroad dollar graphic. Accordingly, such a report could have been the inspiration for Ford's subsequent inclusion of a similar graphic device in its own annual reports.

Summary: Publicly owned U.S. railroads included an early type of stakeholder reporting in their annual reports to shareholders; albeit it years before the first use of the stakeholder term. This usage predates similar reporting efforts in the automobile industry. As the form and content of current annual reports continues to change, it may be useful to look back at earlier forms of stakeholder reporting, such as the examples noted here, to understand how and why they were used.

\section{Exhibit 2:}

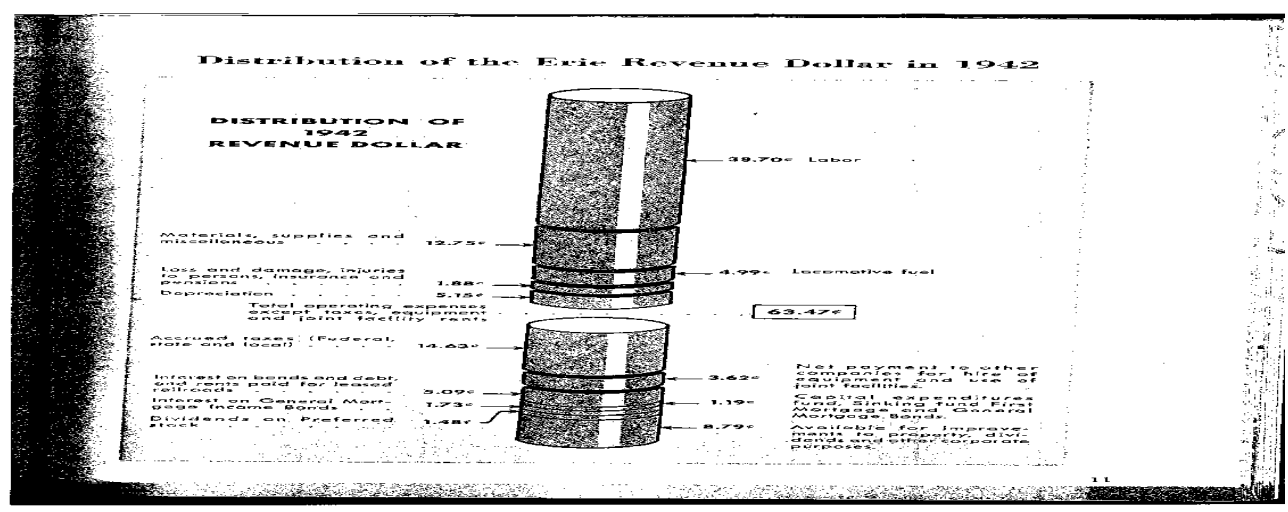

Source: 1942 Erie Railroad Annual Report

\footnotetext{
${ }^{8}$ The 20 railroads in Feeney's study included the many of largest railroads in the U.S. Collectively, the sample group accounted for over $60 \%$ of the total revenue for all Class 1 railroads.
} 


\section{Exhibit 3:}

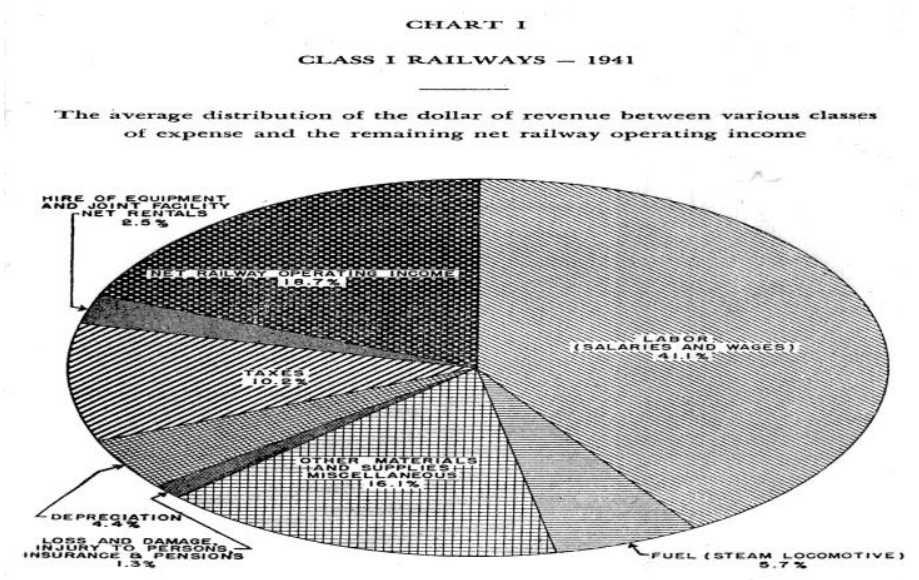

Source: Analysis of Railroad Operations (1946)

\section{References}

Automotive News (2022).http://autonews.com/apps/pbcs.dll/article?AID=/20030616/SUB, viewed on January 4, 2011. (The) Baltimore Sun, December 22, 1955.

Bunnel, E. H. (1955). Railroad Accounting and Statistics: Research and Fact Finding as Aids to Management, Chicago: Watson Publications.

Center for Advancement of Public Policy (2011). http://wwww/capponline.org, viewed on January 6, 2011.

Center for Advancement of Public Policy, Sunshine Standards. (2010). http://www.capponline.org/sunstds. html, viewed on December 21, 2010.

CICA Research Study. (2011). http://www.cica.ca/research-and-guidance/research-activities/activities, viewed on January 5, 2011.

Corporate Social Responsibility Newswire. (2011). http://www.csrwire.com, viewed on January 6, 2011

Corporate Social Responsibility Newswire, National Grid Releases its Annual Corporate Citizenship Report. (2011). http://csrwire.Com/press_releases?30089/-National-Grid-Releases-Its-annualcorpat...,viewedon January 4, 2011.

Debeers Group (2012). http://www.debeersgroup.com/.../id_1353/.../Report_to_Society_2010.PDF , viewed on March 28, 2012.

Eskom. (2011). http://eskom.co.za/annreport2010/sust_stakeholder.htm, viewed on January 3, 2011.

Ethical Corporation. (2011). http://www.ethicalcorp.com/contents.asp?ContentID-4949, viewed on January $4,2011$.

Feeney, K. (2004). Railroad Annual Reports in the Post World War II Era (1946-1975): A Study in Voluntary Compliance, D.P.S. Dissertation, Pace University.

Ford Foundation. (2011). http://www.fordfoundation.org/about-us /history, viewed on January 6, 2011.

Funding Universe. (2011). http://www.fundinguniverse.com/company-histories/The-Ford-FoundationCompany-History, viewed on January 6, 2011.

Harley-Davidson (2011). http://www.harley davison.com/company/investor/ar/1999/pdfs /Harley_1999AR.pdf, viewed on January 4, 2011.

Hudack, L. R. \& Larry, L. O. (1998). The Ford Motor Company's Financial Reporting to Stakeholders - Dormant or Extinct? Published in the Collected Abstracts for the Fifth Charles Waldo Haskin Accounting History Seminar, The Evolution of Business Disclosure, Academy of Accounting Historians, and November 12-14 in Atlanta, Georgia.

Imperial Tobacco Group PLC. (2011). htte://www.imperial-tobacoo,com/index.asp?page=545,viewed on January 3, 2011.

Investors Relations Magazine. (2000). The Visionary Annual Report”, IR Guide \#9. 
Johnson, M. (2011). http://www.matthey.com/substainability2009/our-stakeholders/our-stakeholders.html, viewed on January 3, 2011.

Lawrence, A. \& James, W. (2011).Business and Society: Stakeholders, Ethics, Public Policy, 13thed. New York: McGraw-Hill.

Leonard, W. N. (1948). Book review of Analysis of Railroad Operations. The American Economic Review, 38(1), 199-201.

Niemark, M. K. (1992). The Hidden Dimension of Annual Reports - Sixty Years of Conflict at General Motors, New York: Markus Wiener Publishing, Inc. (The) Pittsburgh Press, December 21, 1955.

Previts, G. J. \& Barbara, M. J. (2000). Exploring the Content of the Baltimore and Ohio Railroad Annual Reports: 1827-1856.The Accounting Historians Journal, 27(1).

Reporting to Stakeholders. (2011). http:/ reportingtostakeholders.blogspot.com?2009/11/us-aicpachairman, viewed on January 5, 2011.

Toyota Motors. (2011).https://www.toyota-global.com/sustainability/stakeholders/toyota_stakeholder _dialogues/pdf/dialogue05060708_en.pdf. viewed on January 3, 2011.

Unilever. (2011). http://unilever.com/substainability /strategy/responding/stakeholder, viewed on January $3,2011$.

Vangermeersch, R. G. (1979. Comments on Accounting Disclosures in the Baltimore and Ohio Annual Reports from 1828 through 1850, Working Paper Series \#38, Harrisonburg VA: Academy of Accounting Historians.

White, J. L. (1946). Analysis of Railroad Operations, $2^{\text {nd }}$ edition, New York: Simmons-Boardman Publishing Corp., 1946.

Whole Foods (2011).http://www.wholefoodsmarket.com/company.com/company/annual-reports.php, viewed on January 3, 2011.

\section{Appendix}

Pages 22-27show examples of Ford's supplemental stakeholder reporting between 1955 and 1979 taken from the Hudack and Orsini (1998) paper and from certain actual Ford Motor Company annual reports.

Pages 28-31show examples of supplemental stakeholder reporting taken from annual reports issued by various publicly owned, Class 1 railroads in the U.S.

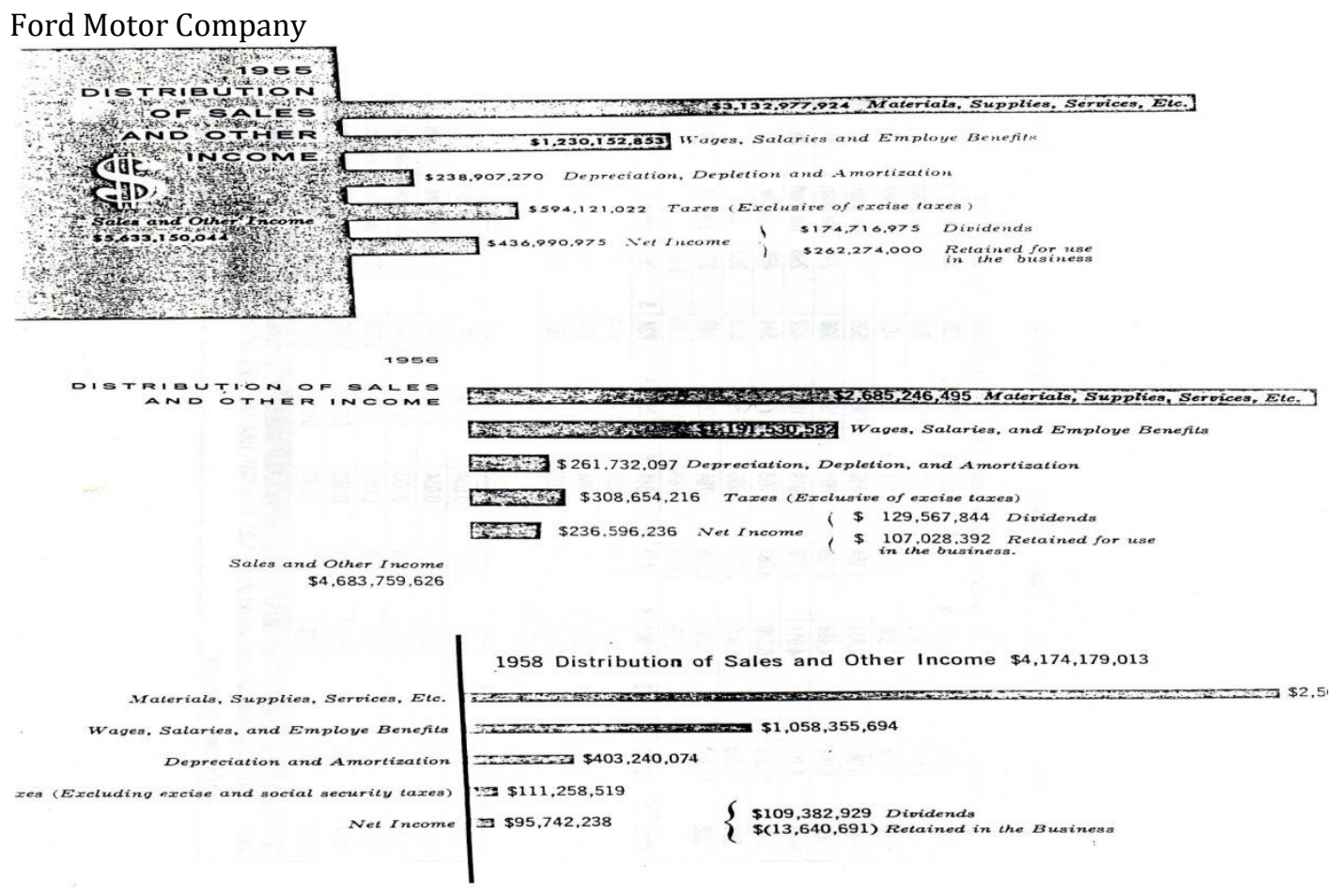



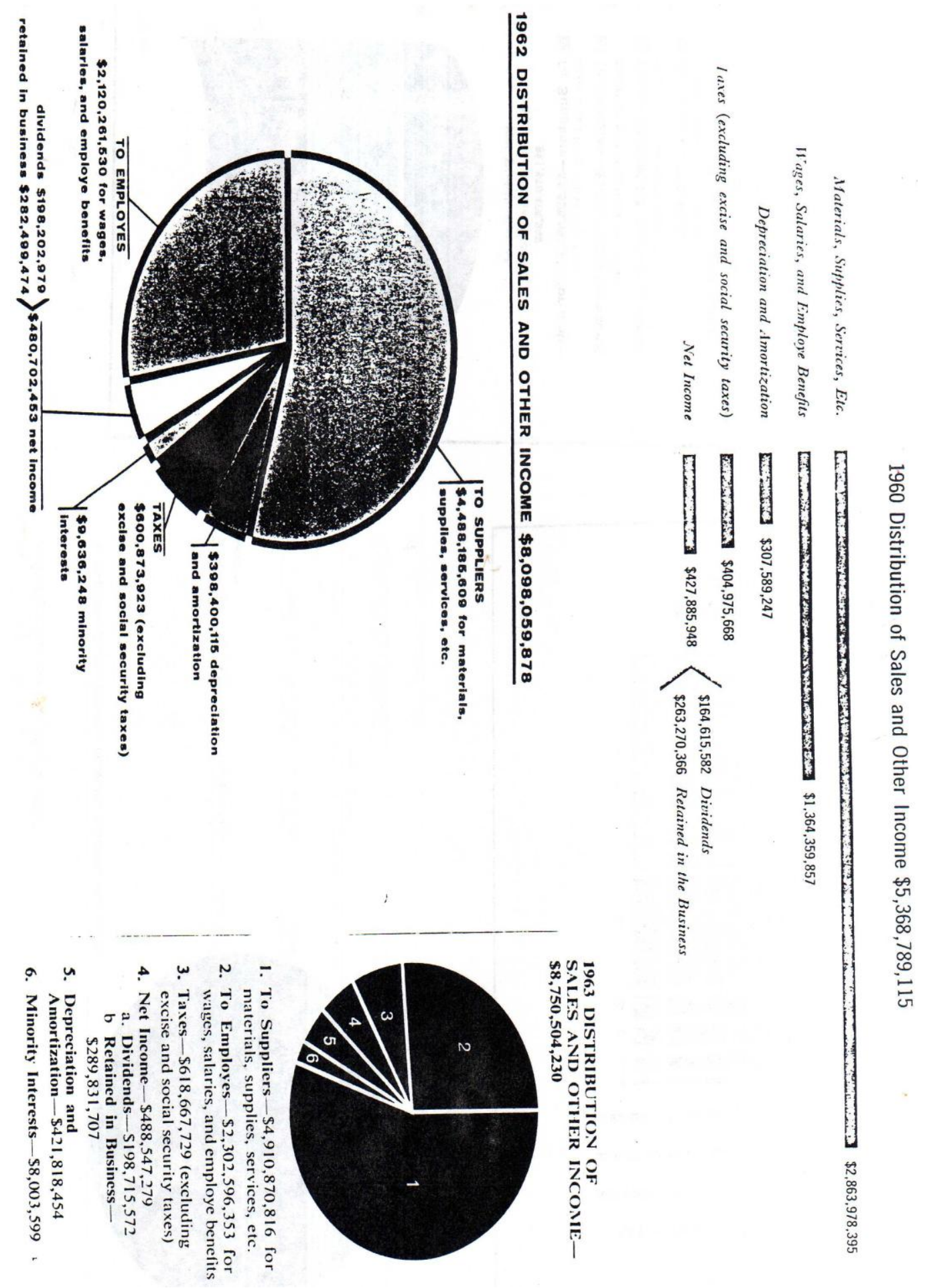


\section{Highlights}

Sales . . . . . . . . . . .

Income before income taxes . . . . . .

Net income

Net income per share . . . . . . . . .

Return on sales . . . . . . . . . . .

Cash dividends per share . . . . . . . .

Capital expenditures for expansion, modernization and replacement of facilities (excludes special tools) . . . . . . . . . . . . . . . Working capital position-year end . . . . . Stockholders' equity-year end . . . . . . Worldwide factory sales-cars, trucks and tractors Worldwide employment-average Worldwide payroll

*Restated for comparative purposes.
$\$ 12,240,047,769$

$\$ 1,166,842,569$

$\$ 621,022,715$

$\$ 5.63$

$5.1 \%$

$\$ 2.40$

$\$ \quad 692,545,940$

$\$ 1,438,275,019$

$\$ 4,782,049,085$

$4,525,170$

388,016

$\$ 2,807,770,038$

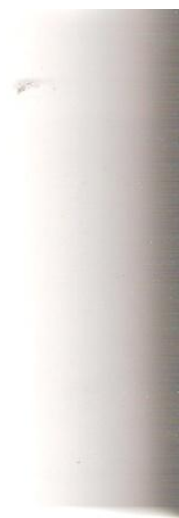

1965

$\$ 11,536,789,264$

$\$ 1,305,282,505$

$\$ 703,048,971$

$\$ 6.33$

$6.2 \%$

$\$ 2.10$

\$ $629,070,543$

$\$ 1,473,340,542$ *

$\$ 4,490,802,002$

$4,595,357$

364,487

$\$ 2,612,987,131$

1966 Distribution of sales

and other income $\$ 12,264,753,992$

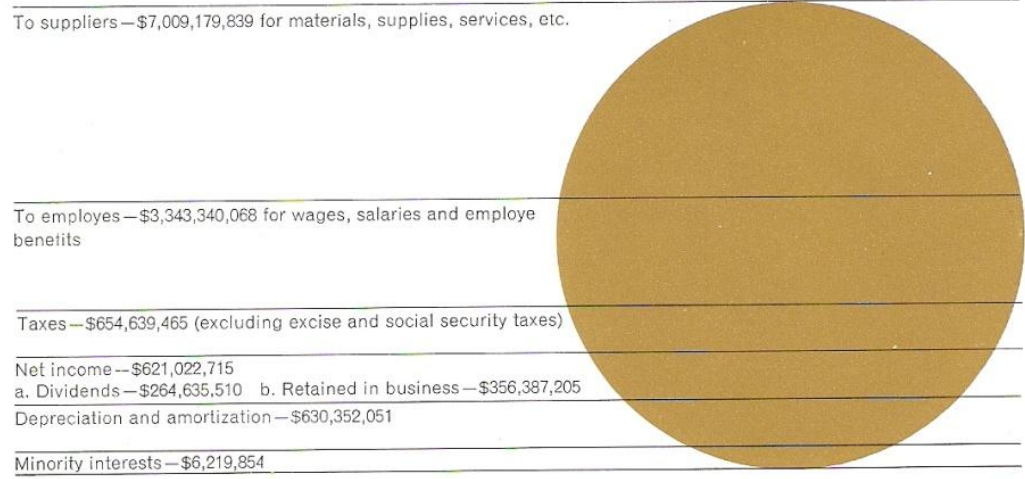




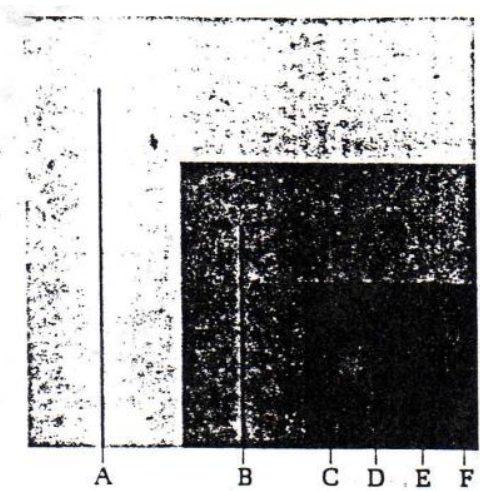

1970 distribution of sales and other income $\$ 15,006$ (in millions of dollars)

A. To suppliers-\$8,601, or $57.3 \%$, for materials, supplies, services, etc.

B. To employes- $\$ 4,413$, or $29.4 \%$, for wages, salaries and employe benefits

C. Depreciation and amortization-\$824, or $5.5 \%$

D. Taxes- $\$ 641$, or $4.3 \%$ (excluding excise and social security taxes]

E. Net income-\$516, or $3.4 \%$ Dividends- $\$ 259$

Retained in business- $\$ 257$

F. Minority interests $-\$ 11$, or $0.1 \%$

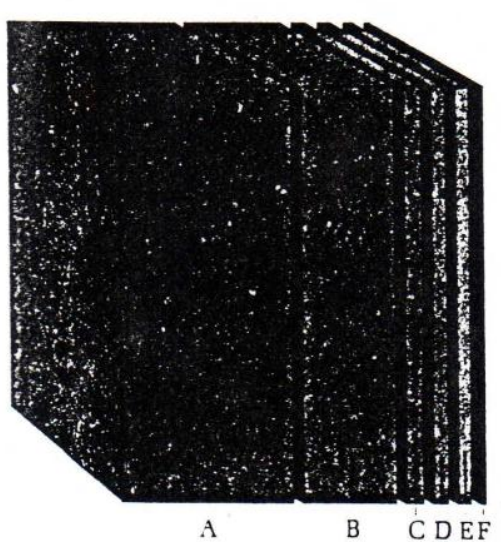

1971 distribution of sales and other income $\$ 16,501$

:n millions of dollars

A. To suppliers $-\$ 9.250$. or $56 \%$, for materiais, supplies, services, etc.

B. To emploves-\$4.765. or $28.9 \%$, for wages. salaries and employe benefits

C. Depreciation and amortizationS824. or $5 \%$

D. Taxes-S994. or $6 \%$. (excluding excise taxes

E. Net income-\$657, or $4 \%$ Dividends $-\$ 265$

Retained in business-\$392

F. Minority interests-S11. or $0.1 \%$
1972 Distribution per dollar of sales and other income $(\$ 20,301.8$ millior

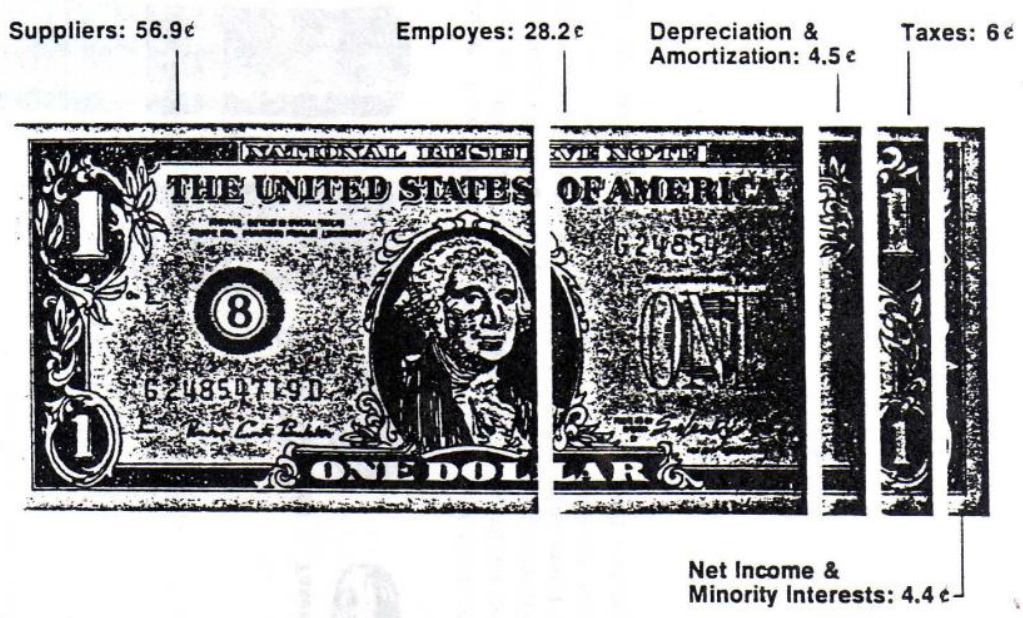

Retained in Business: $3 \mathrm{c}$

Dividends: $1.4 \mathrm{c}$

Distribution of each $\$ 1$ of 1973 Sales and Other Income

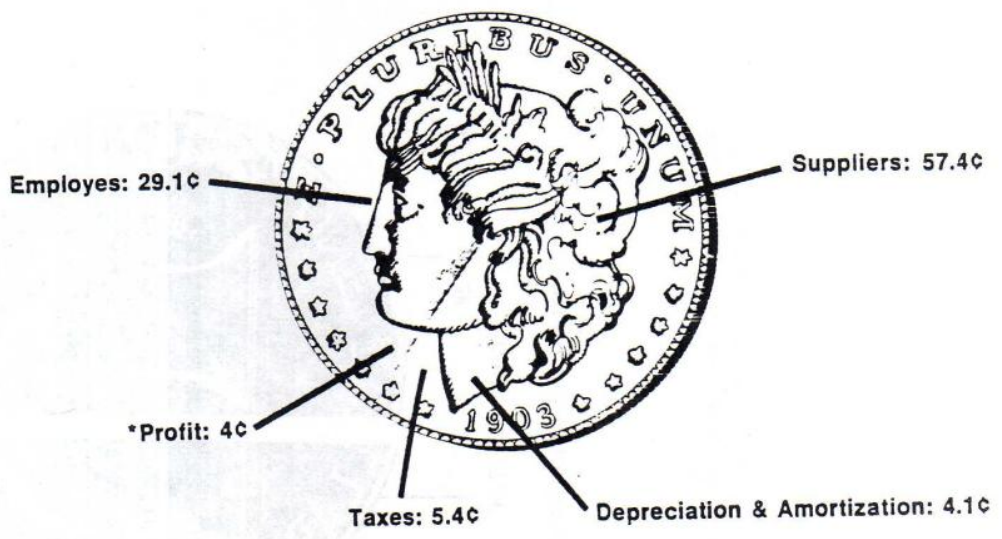

- Profit (income before minority interests) includes $2.5 \mathrm{c}$ of

Retained Earnings, $1.4 \mathrm{e}$ in Dividends and $0.1 \mathrm{e}$ in Minority Interests. 

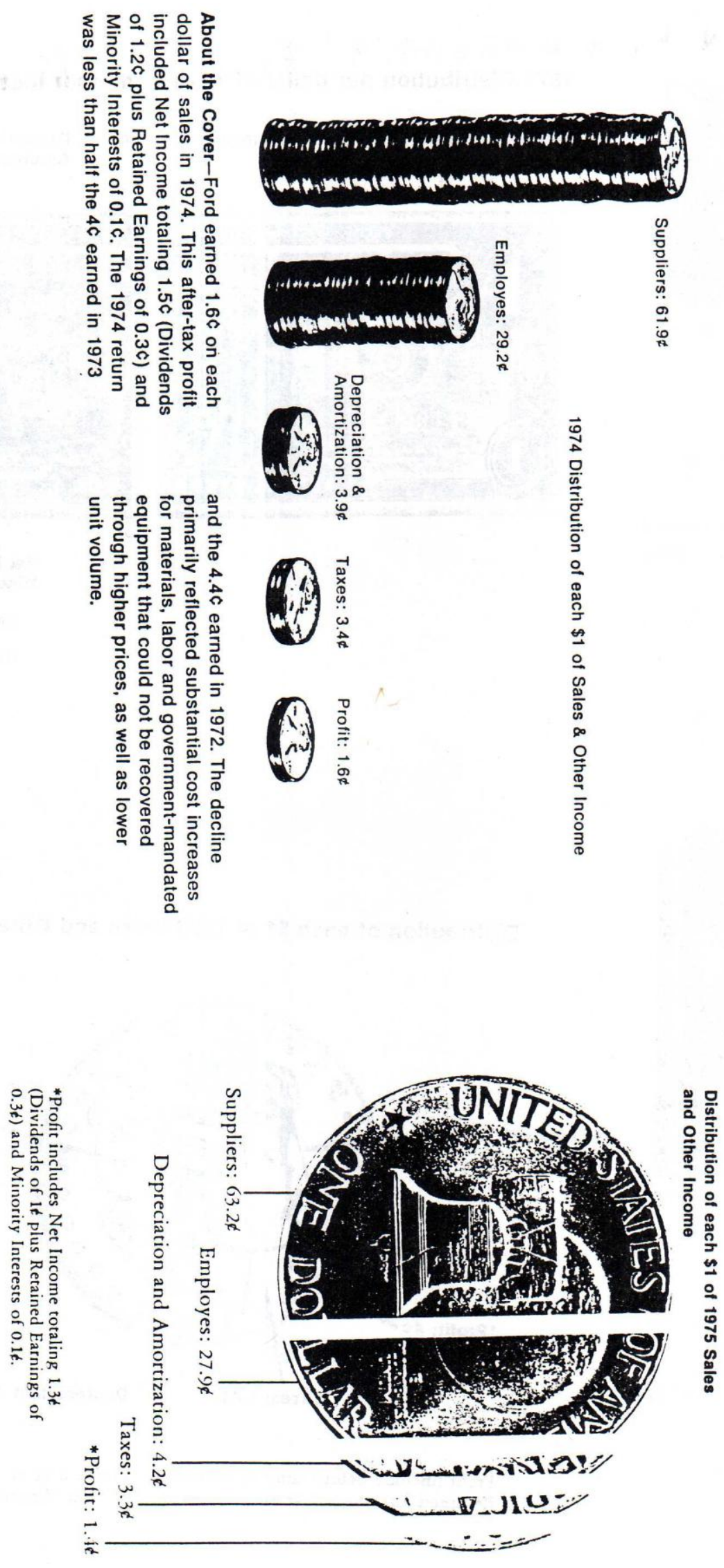

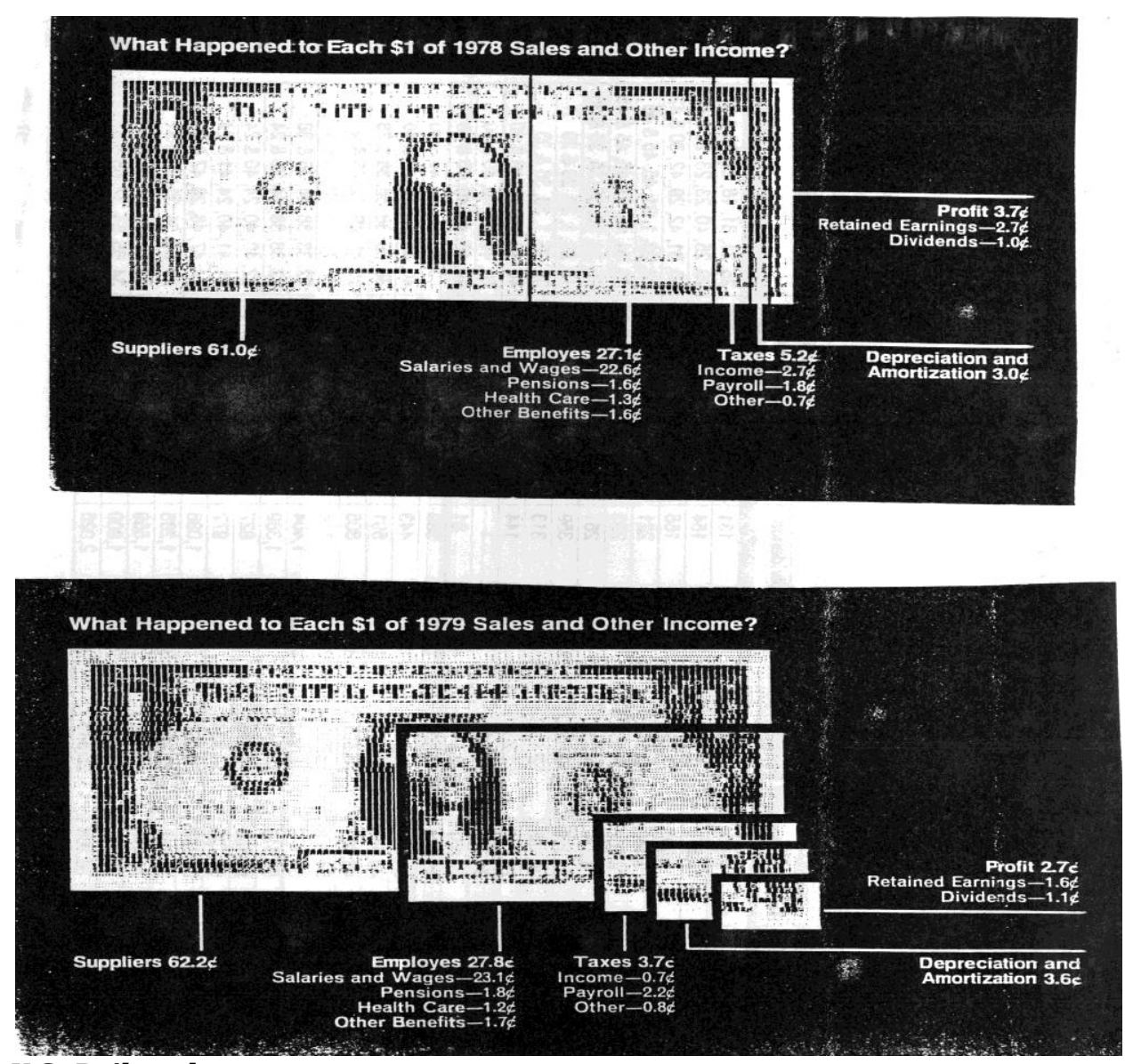

U.S. Railroads

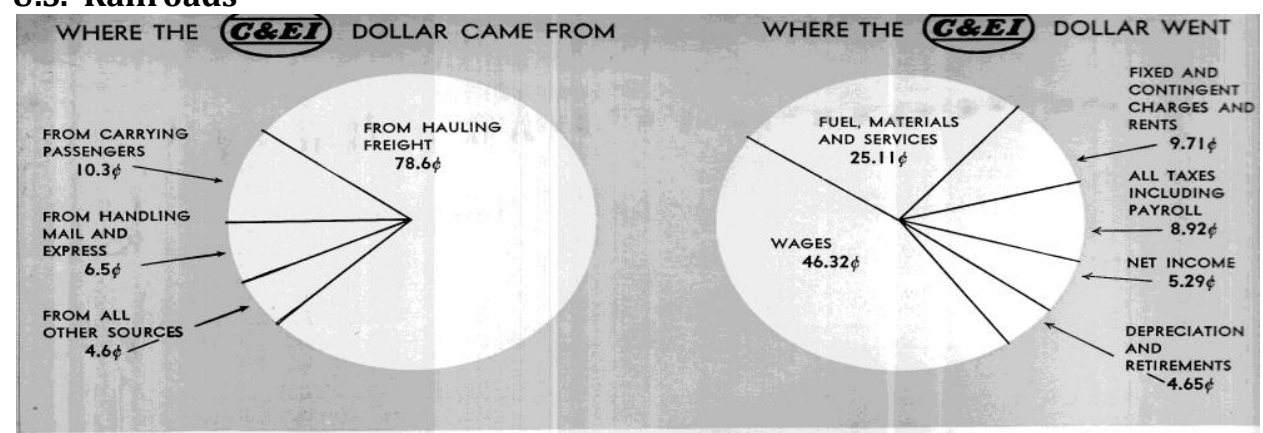

Source: 1951 Chicago \& Eastern Illinois Railroad Annual Report
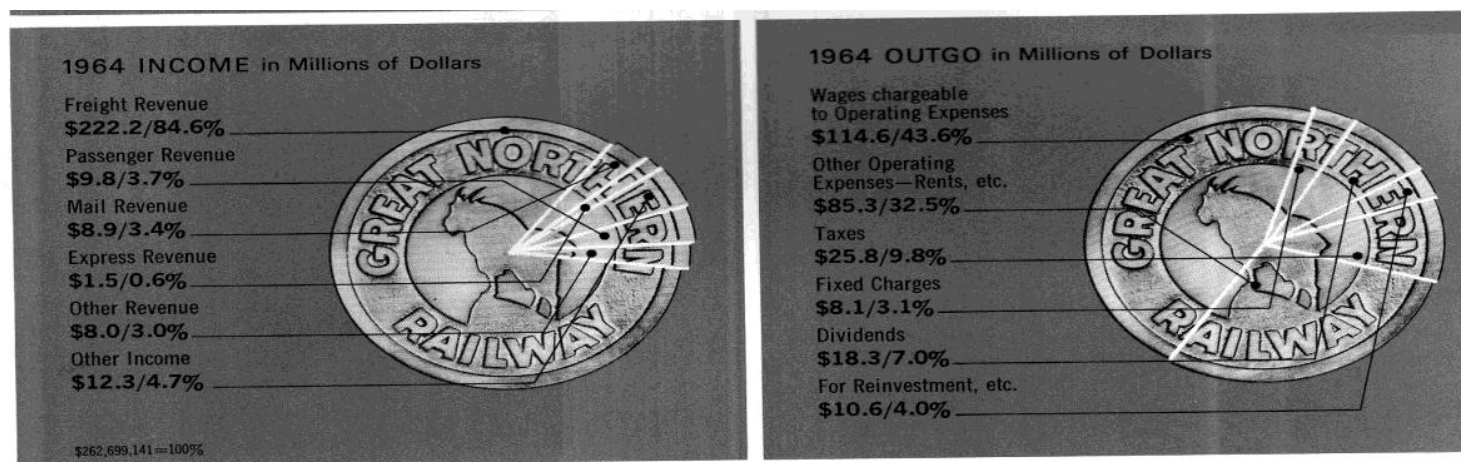

Source: 1964 Great Northern Railway Annual Report 

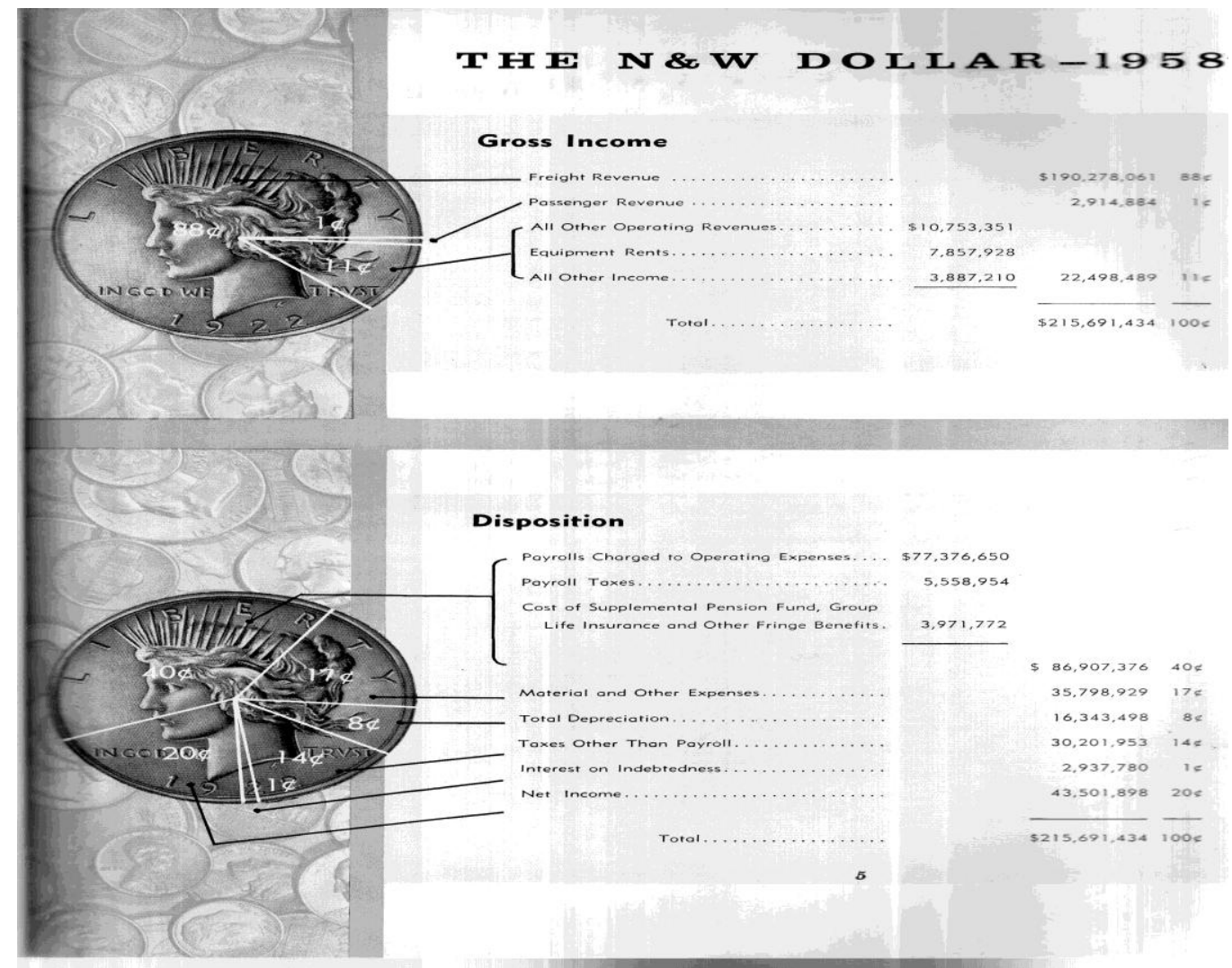

Source: 1958 Norfolk \& Western Annual Report

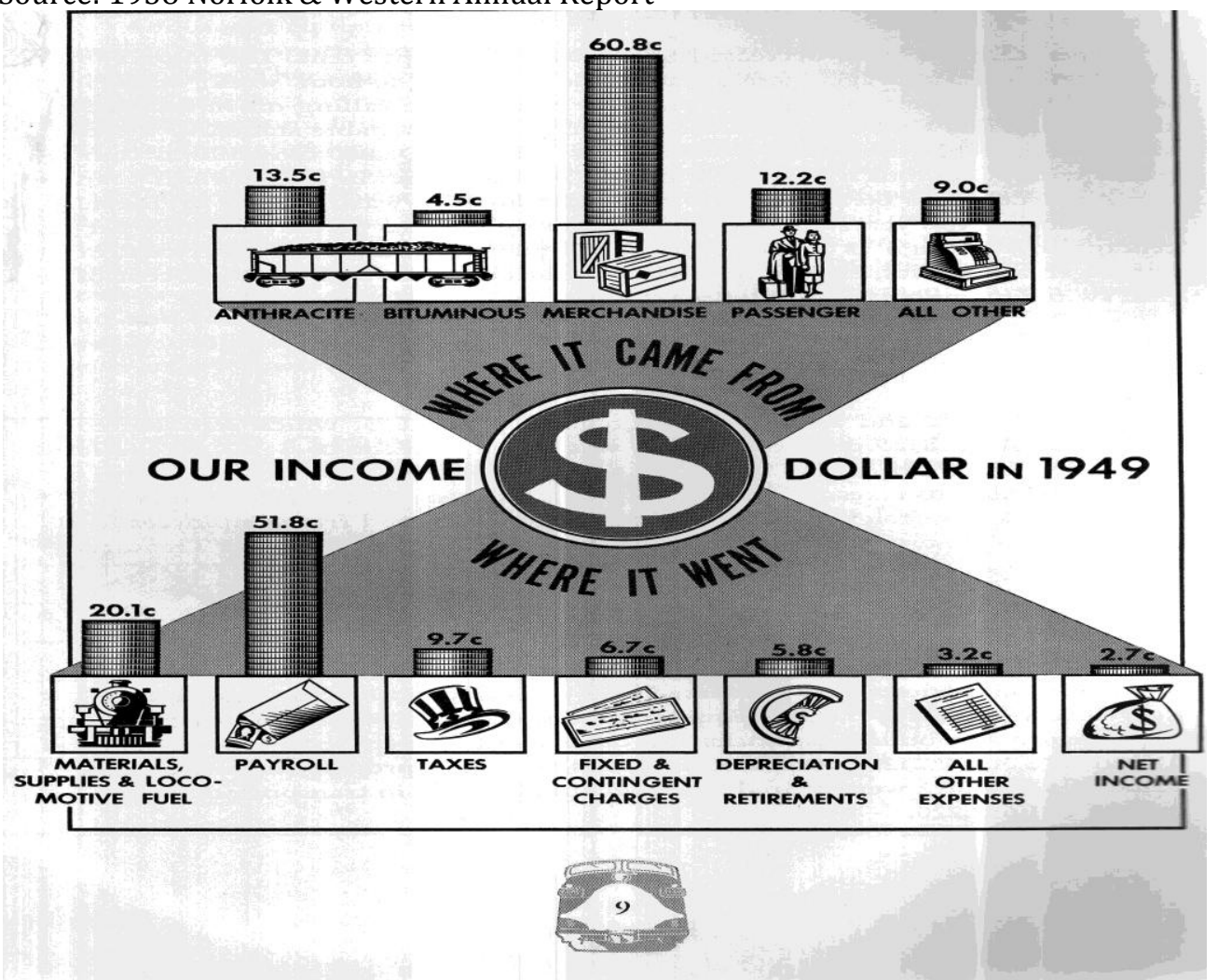

Source: 1949 Delaware, Lackawanna \& Western Railroad Annual Report 


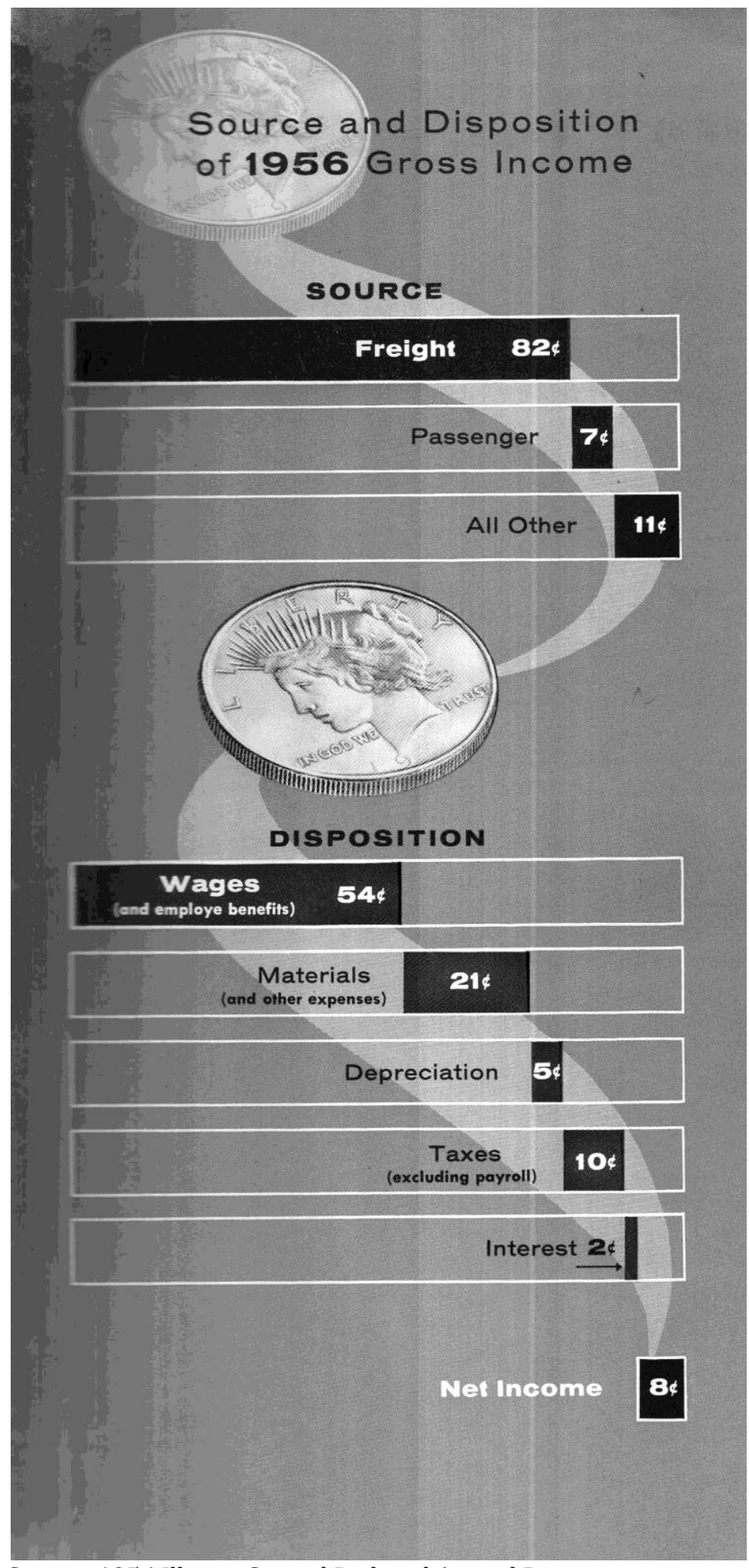

Source: 1956 Illinois Central Railroad Annual Report 